\title{
The Analysis Quintuple Helix Minicont as a challenge for Future Logistics Defense
}

\author{
Ghazalie \\ Indonesian Defense University, Bogor, Indonesia. \\ Aris Sarjito \\ Indonesian Defense University, Bogor, Indonesia. \\ Makmur Supriyatno \\ Indonesian Defense University, Bogor, Indonesia.
}

\begin{abstract}
In supporting competition areas, the International Trade and many kinds of free trade agreements in many industries will become progressively stringent. The implementation of the ASEAN Economic Community increases the need to grow the competitiveness of domestic industries through developing the performance of its logistics system. The Logistic Report Index 2018 was released by the World Bank Indicated that Indonesia rank was in 46th position out of 160 countries. Indonesia will definitely not be able to compete with their ASEAN peers if the development of infrastructure is still poor and logistics cost is higher than another countries. Thefore Indonesia is innovating Minicont-Mini Shipping Container which cutt off by up to $\mathbf{3 0 \%}$ logistics cost and potentially become the next logistic defense. By applying quintuple helix this research is to analyze how Minicont can cut off logitisct cost significantly and support logistic defense in the future. The researchers apply descriptive method for data analysing and the result proved that Minicont shorten supply chain process.
\end{abstract}

Keywords: Logistics Defense, Minicont, and quintuple helix

\section{INTRODUCTION}

Indonesia has strategic position such as the crossroad of the International navigation and transportation, and geographical structure as an archipelagic state which consist of thousands of islands with very long coastlines and exensive sea areas in between which has made Indonesian maritime zones and coast line is very open and porous. Therefore the ports in Indonesia have an important and strategic role for the growth of industry and trade that can contribute to national development. The port as well as one of the transportation infrastructure can generate economic activity in a region as a chain of transportation and logistics systems.

International Business permits organizations worldwide to have a communication as if they are physically close - so physical distances become less significant, and organizations will be becoming global in outlook. They can broaden the suppliers and customers to purchase , transport, store, manufacture, sell and distribute products in a global worldwide market. Many factors enhence global operations, including: Cost differences. Organizations can reduce their overall costs by moving operations to the regions where they can be done least expensively; and Changing logistics. Better logistics makes international trade easier. Such as, containerization and intermodal transport make the movement of goods easier, faster and cheaper. 
Based on global freight forwarders and express carriers worldwide survey indicated that the World Bank's Logistics Performance Index (LPI) is a benchmarking tool developed to measure performance along the logistics supply chain within a country. It compare 167 countries to identify challages and opportunities fot improving their logistics performance. The World Bank executes the survey in every two years. The LPI is based on six indicators such as customs, infrastructure, international shipments, logistic competence, tracking \& tracing and timeliness.

Table 1. Indonesia's Performance in the LPI Indicator

\begin{tabular}{|lccc|}
\hline Indicator & 2014 & 2016 & 2018 \\
\hline Customs & 55 & 69 & 62 \\
\hline Infrastructure & 56 & 73 & 54 \\
\hline International Shipments & 74 & 71 & 42 \\
\hline Logistics Competence & 41 & 55 & 44 \\
\hline Tracking \& Tracing & 58 & 51 & 39 \\
\hline Timeliness & 50 & 61 & 41 \\
\hline
\end{tabular}

It is interesting to note that Indonesia made significant progress in all six indicators every year. This performance has correlation with Indonesian government's effort for developing infrastructure and other related matters, for example the improvement of dwell time in Indonesian ports which has now fallen below four days.

However, if we compare the ranking and score of Indonesia to other lower-middle income economies in Asia, then there is no room for complacency. Indonesia still ranks below Malaysia, Thailand, India and Vietnam (in fact Vietnam overtook Indonesia in the latest LPI). This is a matter because poor connectivity as one of causes high logistics costs, thus implying that Indonesian products and services are not as competitive compared to its regional counterparts.

Table 2. The ranking of ASEAN Countries in the Logistics Performance Index

\begin{tabular}{|lccc|}
\hline Country & 2014 & 2016 & 2018 \\
\hline Singapore & 5 & 5 & 7 \\
\hline Malaysia & 25 & 32 & 41 \\
\hline Thailand & 35 & 45 & 32 \\
\hline Indonesia & 57 & 63 & 46 \\
\hline Vietnam & 48 & 64 & 39 \\
\hline Philippines & 53 & 71 & 60 \\
\hline Cambodia & 83 & 73 & 98 \\
\hline
\end{tabular}

The presence of a new connectivity infrastructure, is not necessarily able to reduce logistics costs. In fact, until now Indonesia's logistics costs are among the most expensive in the Southeast Asia region. PUPR Ministry Director General of Cipta Karya Danis H Sumadilaga said that Indonesia's logistics costs reached 24 percent of total Gross Domestic Product (GDP) while other countries were under 15 percent and even 10 percent. Although not enough attention, but the government will not stop the construction of temporary infrastructure to support the cost of building infrastructure needed for sustainable development. Specifically, for multimodal transportation. Such as, in port construction. The port construction work itself is 
the responsibility of the Ministry of Transportation. However, access to it, both national and toll roads, is the duty of the Ministry of PUPR. The Ministry of PUPR is now building Tanjung Priok access, it's special access. Even in Surabaya also in Patimban, it is also within the framework of supporting the national logistics system. Indonesian Express, Post and Logistics Services Company Budi Paryanto said that governance and regulatory assistance was needed so that infrastructure that could be used more optimally. Seeing the importance of the above, there needs to be a solution that can alleviate national and even global logistics costs. The presence of Minicont (Mini Shipping Container) which is produced by PT. Pelindo Marine Service in collaboration with PT. Semen Indonesia Logistik (SILOG) provides a solution to reduce logistics costs in Indonesia by up to $30 \%$.

A strong national defense will increase the ability to face threats, both from outside and from abroad. Through RI Law No. 3 of 2002 concerning national defense, the concept of national defense underwent a very fundamental change. Article 3 paragraph 2 states that negara National defense is prepared by taking into account the geographical condition of Indonesia as an archipelagic state 'meaning that the orientation of our national defense must be oriented towards archipelagic oriented, not completely land oriented. Therefore Minicont has great potential to be used as the logistics of future defense.

As an archipelagic state, Indonesia has a large portion of the sea area, scattered with large and small islands; and has been recognized by international law through UNCLOS 1982 so that Indonesia has legal legality over its sovereign territory including land, sea and air above. To manage this sovereignty, Indonesia is faced with considerable opportunities and challenges, especially in the field of defense logistics. Indonesia needs logistical capabilities that are able to reach the smallest and outer islands economically and efficiently.

From the perspective of challenges and opportunities, the researchers are interested in analyzing the efficiency of Minicont as a future defense logic. Is Minicont able to become a future defense logistics solution both for Military Operations and Miltary Operation Other Than War) because at this time this product has succeeded in becoming a logistics in sending goods to the smallest, outermost and deepest areas ?. As for the program that has been successfully carried out, the "Container Entry to Village" premiered was carried out by sending as many as 3 (three) tons of rice transported by the Sea Toll Boat, KM. Logistics Nusantara II with the aim of villages in the Essang sub-district of Talaud Regency, North Sulawesi from the Port of Tanjung Perak, Surabaya, East Java.

\section{METHODOLOGY}

Creswell explained that the steps of data collection include efforts to limit research, gather information through observation and interviews both structured or not, documentation, visual materials, and efforts to design protocols for recording or recording information. (John W. Creswell, 2016 p. 253) while Sugiono said that in qualitative research data collection was carried out on natural settings and data collection techniques were carried out with more on participatory observation, in-depth interviews, and documentation. (Sugiyono, op cit pp. 63)

Data were analyzed using several steps in accordance with Miles, Huberman and Saldana's theory (2014), namely analyzing data in three steps: (data condensation), presenting data (data display), and drawing conclusions or verification (conclusion drawing and verification). Data condensation refers to select, focus, simplify, abstract, and transform. In more detail, the steps fit Miles's theory,

Huberman and Salda (2014) will be applied as follows: 
Figure 3.1 Components of Interactive Model Data Analysis Source: Miles and Huberman (Miles, Huberman and Saldana, 2014: 14)

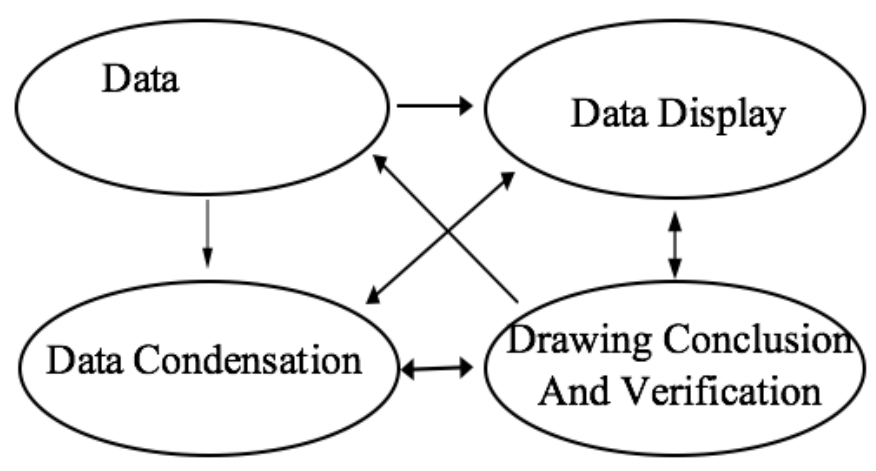

\section{Theory of Quintuple Helix}

\section{LITERATURE REVIEW}

'The Quintuple Helix Model is interdisciplinary and transdisciplinary at the same time : the complexity of the five-helix structure implies that a full analytical understanding of all helices requires the continuous involvement of the whole disciplinary spectrum, ranging from the natural sciences (because of the natural environment) to the social sciences and humanities (because of society, democracy and the economy)' (Carayannis and Campbell 2010, p. 62)

"The Quintuple Helix furthermore outlines what sustainable development might mean and imply for 'eco-innovation' and 'eco-entrepreneurship' in the current situation and for our future” (Carayannis and Campbell 2010, pp. 62-63).

A Quintuple Helix analyzes and makes sustainable development determination for progress therefore each of the five described subsystems (helices) has a special and necessary asset at its disposal, with a social (societal) and academic (scientific) relevance for use (see Figure 3.2; see also Barth 2011a, p. 6 and 2011b, pp. 30-31 ; Meyer 2008, pp. 89-95 ; Carayannis 2004, pp. 49-50), as follows:

1 The education system is the first subsystem which is academia, school, higher education, universities, research centers and training centers. In this helix indicates that the human capital is really important. They are scientists, researchers, students, teachers, academician, experts, entrepreneurs, trainers, etc

2 The economic system is the second subsystem which concern to industries, firms, services and banks. This helix will concentrate and focus to the economic capital such as : entrepreneurship,machines, products, technology, money, etc.

3 The natural environment is the third subsystem for sustainable development and provides people with a natural capital such as : resources, plants, variety of animals, etc.

4 The media-based and culture-based public are the fourth subsystem, which integrates and combines two forms of capital. On the one hand, this helix has, through the culturebased public such as : tradition, values, etc., a social capital. On the other hand, the helix of media-based public such as : television, internet, newspapers, etc. contains also capital of information such as : news, communication, social networks.

5 The political system is the fifth subsystem which is also crucial importance, because it formulates the 'will', where to the state (nation-state) is moving toward in the present and future, thereby also defines, organizes as well as administers the general conditions of the state (nation-state). Therefore, this helix has a political and legal capital such as : ideas, laws, plans, politicians, etc. 
Figure 3.2 The Subsystem of the Quintuple Helix Model.

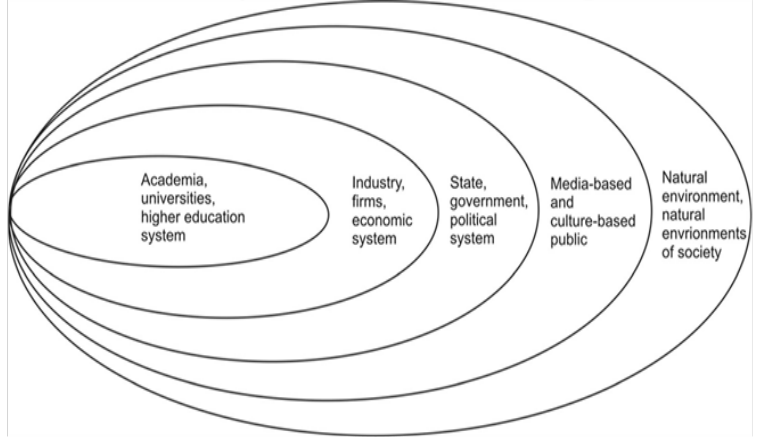

\section{Defense Management Theory}

Defense Management, namely analytical studies of the principles of efficiency, effective coordination and good governance in defense management by utilizing the sciences of organizational management, human resource management, financial management and public sector management (public administration).

In the book 'Tentang Ilmu Pertahana' (2014; pp. 81-115) as rewritten by Joshua Praditya in a Journal (pp. 1-2), the essence of defense management is a policy that is able to guide the Government to build the capability of the defense of the country to be advanced and strong. Defense policy certainly has a strategic impact on every stakeholder in the defense sector, be it civil or military. Strategic impact has three scopes, which are long term, broad impact, and involve many people.

Basically, a country wants the capability of its defense sector to have more advanced capabilities and modernity than surrounding countries, but these countries are faced with limited resources (both natural and man-made). In order to overcome this obstacle, the concept of management is needed, because defense management is a process of managing national resources into national forces in the defense sector, which can be utilized and used effectively and efficiently for the benefit of national defense.

\section{Mini Container (Minicont) concept}

The container is a highly automated system which can move goods from anywhere, to anywhere and is able to minimize cost and complication on the way. It is also able to make shipping cheaper. Everyday thousands of containers are handled by major port which arrive and depart by train and truck. Loaded trucks stream through the gates, where scanners read the unique number on each container and computers compare it against ships' manifests before the trucker is told where to drop his load.

Minicont is abbreviated from 'Mini and Container'. It is a mini shipping container which is simple design, moveable and foldable. The latest PMS product, Minicont which is an innovation and a breakthrough in the world of logistics, can be a support in the success of the Sea Toll declared by President Jokowi's Government. This product was created with a background of understanding that not all regions throughout Indonesia can be passed by container trucks with a capacity of 20 feet. One other advantage is that Minicont can be folded when it is empty and 9 units of Minicont fold can be put in a 20 feet container.

Minicont initiated by PMS because it can be transported using pioneer ships and small trucks to reach T3P areas (lagging, remote, outermost, and border areas, the government is developing end-to-end integrated and connected sea tolls that connect between regions in 
Indonesia and can reach T3P areas ( lagging, remote, outermost, and border) Then the cargo is transported to the pioneer ship (KM Sabuk Nusantara) to the local feeder port. The pioneer ship is a small ship with a weight of 2000 GT so that it perfectly matches the characteristics of MiniCont which is about 7 teus size. by LCT 50 GT and PELRA 35 GT ships to be sent to remote islands such as Miangas, Kakorotan, Sanana, Bovendigul, Giving etc. With the dimensions and characteristics of MiniCont, Capt. Wisnu is optimistic that the sea toll program can work well to reach the T3P area throughout Indonesia MiniCont - The Next Logistic Solution

\section{The Analysis Quintuple Helix Minicont}

\section{The Education Sector}

The education sector defines itself in reference to academia, universities, higher education systems, and schools. In this helix, relates to the human capital such as : students, teachers, scientists / researchers, academic entrepreneurs, etc. of a state (nation-state) which is being formed by diffusion and research of knowledge. In the field of Education PT. Pelindo Marine Service (PT PMS) has collaborated with the Nusantara Maritime Research Institute (Marin Nusantara) in initiating the 'Container Entry to Villages' program, which is sending rice to remote areas in North Sulawesi. In addition, PT PMS also often receives visits from various universities such as receiving Defense Management students to conduct logistics management research. The visit was led by the Dean of the Defense University, Laksda TNI Sulistiyanto, SE, MM, M.Sc., PSC and the lecturers were welcomed by the Director of PT PMS, Eko Hariyadi Budiyanto in the VIP room at Gapura Surya Nusantara in Surabaya, Indonesia precisely on 30 October 2018.

\section{The economic sector}

The economic sector consists of industries, firms, services and banks. The helix will both concentrate and focus the economic capital such as : entrepreneurship, machines, products, technology, money, etc. of a state (nation-state). Minicont innovation is a synergy collaboration between BUMN, which is carried out through collaborative design preparation and prototype Minicont between PT Pelindo Marine Service as a subsidiary of PT Pelabuhan Indonesia III (Persero) with PT Semen Indonesia Logistik (SILOG) which is one of the subsidiaries of PT Semen Indonesia (Persero) Tbk. through the Division of Industrial Goods \& Fabrication Business Fields which have 44 years of experience in fabrication.

As for the manufacture of the Minicont 100\% uses local (domestic) components. For transportation of Minicont, Eko Hariyadi added, it can use a CDD (Colt Diesel Double) truck which is currently ready on the market with 6 tires and a sturdy chassis to carry heavy loads up to $7,500 \mathrm{~kg}$, by making a slight modification of the flat deck so that it can be used to hold 2 Minicont units for each CDD truck unit. "The prototype project for the Minicont and flat deck is now ready to be exhibited and it is planned that next year it will be mass produced until it reaches around 1,000 Minicont units.

By using Minicont there are two advantages, first, cost efficiency means eliminating the function of the local warehouse and depot as a transit point for goods from containers to box trucks, logistics planning to stores is done at the distribution center, no longer at the local warehouse, all warehouse operating costs local including manpower and inventory costs will be lost, saving repositioning costs of Rp 2-3 million / 20 'container. The 9-unit Minicont can be folded and put into 1 unit 20 'container during the repositioning process. And second, the acceleration of the distribution process, in the absence of a local warehouse, the process of handling in / out and sorting of goods in the local warehouse will be lost, thus speeding up the delivery time (lead time) 4-6 days and speeding up the distribution of goods to enter regions 
that are difficult to reach by truck containers in general. The features of Minicont are construction material from mild steel and aluminum so that it is durable; Fire, water, wind and rodent resistant; Rust resistant paint coating; Equipped with a forklift hole; Can be placed on diesel colt; and Can be folded when the condition is empty.

\section{The Natural Environtment}

The natural environment aims to sustain the development and provides people with a natural capital of Indonesia's vast ocean as a sustainable resource. Based on Republic of Indonesia Law No. 6 of 1996 concerning Indonesian waters, it is stated that Indonesia has sovereignty in Indonesian waters, with areas consisting of inland waters, waters of the islands and Indonesian territorial seas. In accordance with the provisions of the sea law which states that the coast / islands in the exclusive economic zone (EEZ) and continental shelf have sovereign rights (sovereign right).

Director of Sea Traffic and Transportation, Capt. Wisnu Handoko in Jakarta explained that the mini container (Minicont) is useful for reaching areas that have limited access to loading and unloading equipment at the Port and access roads. "With the container program entering the village, of course, it will support the sea highway program with an end to end scheme. And with this program it is hoped that the presence of the state will be increasingly felt by the community, especially in the 3TP area (Behind, Leading, Remote and Remote) and can reduce price disparities between Western Indonesia and Eastern Indonesia, ".

The first "Container Enter Village" program is carried out by sending as many as 3 (three) tons of rice to the villages in Essang which is one of the areas in the Talaud Islands Regency of North Sulawesi. The means used to make the shipment is "Minicont" or mini container which is one of the innovative products of one of the subsidiaries of PT Pelabuhan Indonesia III (Persero), namely PT Pelindo Marine Service.

This Minicont was chosen as a means of delivery in the "Container Entry to Village" program due to the flexibility and efficiency of the Minicont itself, where it can be folded so as to save space when returning empty containers. A total of 3 (three) Miniconts can be put into a 20 "container, while 8 (eight) Miniconts that have been folded can be put into a 20" container. So that it is expected to reach remote areas that cannot be passed by large trucks.

\section{The Media-Based And Culture-Based Public}

The media-based and culture-based public integrate and combine two forms of capital. PT Pelindo III (Persero) took part in the 2018 IMF-World Bank Group annual event held on the Island of the Gods by exhibiting an innovation work produced by the synergy of a State-Owned Enterprise (BUMN) between PT Pelindo Marine Service (PMS) with PT Semen Indonesia Logistik (SILOG) named Mini Container (Minicont). This was revealed by the President Director of PT. Pelindo Marine Service (PMS), Eko Hariyadi Budiyanto, said that his party would like to introduce to the shipping business and shipping companies a mini container that has the same strength as containers in general.

In his presentation Mr. Eko as the leader of the company explained that his company prioritizes the spirit of Lets Go Beyond Marine, and currently PMS has 3 subsidiaries engaged in channel management (APBS), energy \& LNG terminals (PE Logistics), and logistics (BMC). Furthermore, specifically and in detail he introduced a new innovation product as a solution to the national logistics problem, namely Minicont. Minicont is made by PT. Pelindo Marine Service with PT PT Semen Indonesia Logistics. This is the synergy of BUMN companies 


\section{The Political Sector}

The political sector is also very important because it designs the 'will', where to the state (nation-state) is moving toward the present and future, also defines, organizes as well as covers the general conditions of the state (nation-state). When the 7th Prime Minister's Speech was RI. Joko Widodo is a momentumthat we must guard and fight together as elements of a whole and dignified nation for the purpose of becoming a large and sovereign nation. The spirit that was proclaimed by the Indonesian government through a speech at the inaugural session of the MPR on October 20, 2014 was the spirit of maritime :

"We have turned our backs on the sea, our backs on the ocean, and our backs on the strait and bays. It's time we return everything so that 'Jalesveva Jayamahe', in the sea we actually triumph, as our motto in the past can comeback. " (Joko Widodo, 2014)

The statement above shows the political steps taken by President Jokowi in leading Indonesia in his future administration. Indonesia as an archipelago with more than 17 thousand islands scattered certainly has challenges in regulating the national logistics system. One of the challenges that must be faced is the high cost of logistics and the number of remote areas that have not even been touched due to the difficulty of access to land transportation to these places. PMS as one of the BUMN subsidiaries answered the logistical problem by providing a quick and practical solution by simplifying the transportation equipment that can cut the distribution lines and reach all corners of the archipelago.

The government is currently developing an end-to-end integrated and connected Iaut Toll that connects between regions in Indonesia and can reach T3P areas (backward, remote, outermost, and border) in optimizing and succeeding the Sea Toll Program initiated by the Joko Widodo administration, the Ministry of Transportation through the Directorate General of Sea Transportation cq the Directorate of Sea Traffic and Transport (Dirlala) in collaboration with PT Pelindo Marine Service (PMS) created the latest innovation called Minicont (Mini Container).This innovation is a breakthrough in the logistics world and can be a support for the success of the Sea Toll Program One program that has been successfully carried out is the "Container Entry to Village" Program is the result of the synergy of BUMN, namely PT Pelni as a boat operator, PT Pelindo Marin Service as a provider of Mini Containers, Perum Bulog as a product supplier and Village Owned Enterprises (Bumdes) as a product distributor.

\section{Conclusion}

\section{CONCLUSION AND SUGESSTION}

Based on Quintuple helix analysis, Minicont's innovation products have met the principles of defense management as explained in the theory above, namely the principles of efficiency, effective coordination and good governance. Minicont product innovation is as a result of the synergy of several BUMN, PT Pelindo III and its subdiaries of PT. Pelindo Marine Service as a Brand owner with PT Semen Indonesia and its subdiary of PT Semen Logistik Indonesia as a producer, and the Ministry of Transportation through the Directorate General of Sea Transportation cq. Directorate of Sea Traffic and Transportation (Dirlala).

Whereas in the case of the implementation of the "Container Entry to Village" Program is the result of the synergy of BUMN namely PT. Pelni as a ship operator, PT. Pelindo Marin Service as a provider of Mini Container, Bulog as a supplier of products and Village-Owned Enterprises (Bumdes) as a distributor of products. In the future Minicont can create, equip, sustain and monitor the armed forces in the field to meet operational demands within the limits of size and composition if they can be realized in synergy with BUMN Defense Strategic 


\section{Recomendations}

1. PT. PMS must improve the education sector by involving young researchers from various universities in Indonesia to improve the quality of Minicont products and develop with various variants for both commercial and national defense interests.

2. Building synergy with the ministry of defense and National Strategic BUMN such as PT. PAL, PT. Pindad to make minicont as future defense logistics.

\section{References}

\section{Books}

Carayannis, Elias \& Campbell, David. (2018). Smart Quintuple Helix Innovation System: How Social Ecology and Environmental Protection are driving Innovation, Sustainable Development and Economic Growth. Springer International Publishing : Switzerland

Donald W, (2007). Global Logistic ; New directions in supply chain management., Kogan Page : United Kingdom (2007). Global Logistics: New Directions in Supply Management, Kogan Page : United Kingdom (2007). Supply Risk Management: Vulnerability and Resilience in Logistics, Kogan Page : United Kingdom Forbes, Andrew. (2007). Sea Power: Challenges Old and New, Halstead Press: Sydney

John, F and leigh, S., (2014). Logistics and retail Management: emerging Issues and New challanges in Retail Supply Chain , United Kingdom:

Levinson,M., (2006) The Box: How Shipping Container Made The World Smaller And The World Economy Bigger, United Kingdom:

Makmur Supriyatno dan Yusuf Ali. (2018). Pengantar Manajemen Pertahanan, Universitas Pertahanan Press: Bogor

Rickey.Martono. (2018). Logistics Management. Jakarta:

Susantono, Bambang. (2013) Transportasi Dan Investasi: Tantangan Dan Perspektif Multidimensi. Penerbit Buku Kompas: Jakarata

Setiadji, Agus. (2016) Alutsista dan Poros Maritim Dunia, Indotech Dharma digdaya: Jakarta

Supriyatno, Makmur. (2014) Tentang Ilmu Pertahanan. Yayasan Obor Indonesia: Jakarta

\section{Jurnal and Online Resources}

Carayannis, Elias \& Campbell, David. (2009). 'Mode 3' and 'Quadruple Helix': Toward a 21st century fractal innovation ecosystem. International Journal of Technology Management - INT J TECHNOL MANAGE. 46. 10.1504/IJTM.2009.023374.

Carayannis, Elias \& Barth, Thorsten \& Campbell, David. (2012). The Quintuple Helix innovation model: global warming as a challenge and driver for innovation. Journal of Innovation and Entrepreneurship. 1. 10.1186/21925372-1-2.

Faturahman, Burhanudin \& Rozikin, Mochamad. (2017). Innovation of Local Government in Improving Food Security in Pacitan Regency. 4.

Setu Embu, Wilfridus. (2018). 'Pelindo III Ciptakan MiniCon, Kontainer Mini Solusi Masalah Logistik', [www.document] htpp : // www.liputan6.com (accessed 7 August 2019)

Prabowo,Dani. (2019). 'Biaya Logistik Indonesia Masih Mahal'[www.document] htpp : // Properti.kompas.com (accessed 7 August 2019)

Ekbis. (2018). 'PMS Kenalkan Mahasiswa Pasca Sarjana Universitas Pertahanan Dunia Bisnis Maritim', [www.document] htpp : // www. titikkomapost.com (accessed 14 August 2019)

Nur Cahya Aryani,Gusti. (2018). 'Mini container minicont cuts nearly 30 percent of logistics costs', [www.document] htpp : // en.antaranews.com (accessed 14 August 2019)

Christatnto,Deni (2019). 'Program “Kontainer Masuk Desa” perdana dilakukan dengan mengirimkan sebanyak 3 (tiga) ton beras ke desa-desa di Essang', [www.document] htpp : // www.pelindomarine.com (accessed 14 August 2019) 
Kemenhub. (2019). 'Sukseskan Program Tol Laut Kemenhub-PMS Gagas Mini Container', [www.document] htpp : // Tribunnews.com (accessed $17 \mathrm{Au}$ gust 2019)

ekbis. (2018). 'PMS Pamer Minicont Di Ajang IMF-World Bank Group 2018', [www.document] htpp : // www.titikomapost.com (accessed 21 August 2019)

\section{Perundangan}

Undang-undang RI No 3 Tahun 2002 tentang Pertahanan Negara

Undang-undang RI nomor 6 tahun 1996 tentang perairan Indonesia 